\title{
Fen Bilimleri Dersi Kapsamında Planetaryuma Düzenlenen Bir Gezinin 7. Sınıf Öğrencilerinin Akademik Başarı, İlgi ve Motivasyonuna Etkisi ${ }^{1}$
}

\author{
Murat METIN \\ Tokat Gaziosmanpaşa Üniversitesi \\ mrtmtn6005@hotmail.com \\ Aykut Emre BOZDOĞAN \\ Tokat Gaziosmanpaşa Üniversitesi \\ aykutemre@gmail.com
}

Gönderilme Tarihi: 23/03/2020

Kabul Tarihi: 28/06/2020

Yayınlanma Tarihi: 29/07/2020

DOI: $10.30855 /$ gjes.2020.06.02.004

\begin{tabular}{|c|c|}
\hline Makale Bilgileri & ÖZET \\
\hline $\begin{array}{l}\text { Anahtar Kelimeler: } \\
\text { Okul dışı öğrenme, } \\
\text { Fen bilimleri dersi } \\
\text { öğretim programı, } \\
\text { Planetaryum }\end{array}$ & $\begin{array}{l}\text { Bu araştırmanın amacı, Fen Bilimleri dersi kapsamında planetaryuma } \\
\text { düzenlenen bir gezinin } 7 \text {. sınıf öğrencilerinin akademik başarı, ilgi ve } \\
\text { motivasyonuna etkisini araştırmak ve planetaryumları fen dersinde } \\
\text { kullanılmasına ilişkin öğrenci görüşlerini belirlemektir. Bu amacı } \\
\text { gerçekleştirmek üzere planetaryum gezisi ile entegre edilmiş ve } 5 \mathrm{E} \text { modeline } \\
\text { uygun olarak hazırlanmış ders planı uygulanmıştır. Araştırma problemine } \\
\text { cevap aramak adına nicel ve nitel veriler toplanmış bu sebeple karma yöntem } \\
\text { kullanılmıştır. Araştırmanın çalışma grubunu 2019-2020 öğretim yılında } \\
\text { Amasya ilinde bir köy okulunun } 7 / \text { A ve } 7 / \text { B şubelerinde yer alan } 327 \text {. sınıf } \\
\text { öğrencisi oluşturmaktadır. Örneklem seçiminde Uygun Örnekleme Yöntemi } \\
\text { kullanılmıştır. Veri toplama aracı olarak nicel verilerin toplanmasında 'Güneş } \\
\text { Sistemi Ötesi: Gök Cisimleri Akademik Başarı Testi', 'Fen Konularına Yönelik } \\
\text { İlgi Ölçeği' ve 'Fen Öğrenimine Yönelik Motivasyon Ölçeği' kullanılmış ve } \\
\text { gruplara ön test-son test şeklinde uygulanmıştır. Veri analizinde SPSS } 22 \\
\text { programı ile Shapiro-Wilk normallik testi, istatistiksel hesaplamalar için ise } \\
\text { Bağımsız Örneklem t-Testi kullanılmıştır. Nitel verilerinin toplanmasında ise }\end{array}$ \\
\hline
\end{tabular}

\footnotetext{
${ }^{1} \mathrm{Bu}$ araştırma, Prof. Dr. Aykut Emre BOZDOĞAN'nın danışmanlı̆̆ında Murat METiN tarafından hazırlanan Yüksek Lisans tezine dayanmaktadır

Metin, M., \& Bozdoğan, A. E. (2020). Fen bilimleri dersi kapsamında planetaryuma düzenlenen bir gezinin 7. sınıf öğrencilerinin akademik başarı, ilgi ve motivasyonuna etkisi. Gazi Eğitim Bilimleri Dergisi, 6(2), 240-260. DOI: https://dx.doi.org/110.30855/gjes.2020.06.02.004
}

Dergi Web Sayfast: http://dergipark.gov.tr/gebd 
öğrenci görüşlerinin belirlenmesi amacıyla gezi öncesi ve gezi sonrası görüşme soruları kullanılmıştır. Veriler içerik analizi ile değerlendirilmiştir. Araştırma sonucunda okul dışı öğretimin planlı bir şekilde yürütüldüğü takdirde amacına ulaştığ1, mevcut öğretime göre planetaryum gezisi ile öğretimin öğrenci başarısını, öğrencilerde fen konularına yönelik ilgi ve fen öğrenmeye yönelik motivasyon düzeyini anlamlı ölçüde artırdığı tespit edilmiştir. Başlangıçta planetaryum ile ilgili hiçbir fikri olmayan öğrencilerin bu ortamı tanıdığı, eğlenceli ve öğretici bulduğu görülmüştür. Bu araştırma ile okul dışı öğrenme ortamlarından biri olan planetaryumların tüm eğitim kademelerinde planlı etkinlikler yapılarak etkili bir eğitim aracı olarak kullanılabileceği ve eğitim sistemi ile entegre edilerek yaygınlaştırılması önerilmektedir.

\section{The Effect of a Trip Organized In Planetarium on Science Course on Academic Success, Interest and Motivation of 7th Year Students}

\begin{tabular}{|c|c|}
\hline Article Info & ABSTRACT \\
\hline $\begin{array}{l}\text { Out-of-school } \\
\text { education (Outdoor } \\
\text { school-ODS), } \\
\text { Science education } \\
\text { curriculum, } \\
\text { Planetarium }\end{array}$ & $\begin{array}{l}\text { The purpose of this study is to investigate the effect of a trip organized on a } \\
\text { planetarium within the scope of the Science course on academic success, interest } \\
\text { and motivation of } 7 \text { th grade students and to determine student views on the use } \\
\text { of planetariums in a science lesson. To accomplish this goal, the lesson plan, } \\
\text { which was integrated with the planetarium trip and prepared in accordance } \\
\text { with the } 5 \mathrm{E} \text { model, was implemented. Quantitative and qualitative data were } \\
\text { collected to find answers to the research problem, and therefore mixed method } \\
\text { was used. The study group of the research consists of } 32 \text { 7th grade students in } \\
\text { the } 7 \text { / A and } 7 \text { / B branches of a village school in the province of Amasya in the } \\
\text { 2019-2020 academic year. Appropriate Sampling Method was used in sample } \\
\text { selection. In the collection of quantitative data as the data collection tool, } \\
\text { "Beyond Solar System: Celestial Bodies Academic Achievement Test", "Science- } \\
\text { Related Interest Scale" and "Science Learning Motivation Scale" were used and } \\
\text { applied to groups as a pre-test and post-test. In the data analysis, SPSS } 22 \\
\text { program used the Shapiro-Wilk normality test and Independent Sample t-Test } \\
\text { for statistical calculations. In the collection of qualitative data, pre-trip and post- } \\
\text { trip interview questions were used to determine student views. The data were } \\
\text { evaluated by content analysis. As a result of the research, it has been determined } \\
\text { that if out-of-school education is carried out in a planned manner, it has } \\
\text { significantly increased student achievement, interest in science subjects and } \\
\text { motivation to learn science with the planetarium trip according to the current } \\
\text { education. It was seen that the students who had no idea about the planetarium } \\
\text { initially recognized this environment and found it fun and instructive. With this } \\
\text { research, it is recommended that planetariums, which are one of the out-of- } \\
\text { school learning environments, can be used as an effective educational tool by } \\
\text { carrying out planned activities at all educational levels and can be expanded by } \\
\text { integrating with the education system. }\end{array}$ \\
\hline
\end{tabular}




\section{GİRIŞ}

İnsanoğlu eski çağlarda dikkatini çeken her olayı merak etmiş ve bu merakı sonucu ulaştığı bilgileri de kayalara ve mağara duvarlarına işlemiştir. Merak edilen en önemli alan ise gökyüzü olmuştur. Yerleşik hayatla birlikte avcılıktan tarım toplumuna geçiş sonrasında tarım yapmak için önemli olan takvim bilgisi ve mevsimlerin zamanı gibi bilgilere ihtiyaç duyulmuştur. Takvim, mevsim gibi kavramlar ise gökcisimlerinin yapısı, hareketlerinin anlaşılması ve gizeminin çözülmesine bağlı olmuştur. Yine ticaretin gelişmesi ve kervanların yön bulma ihtiyaçları, dini inanç sistemlerinin gelişmesi ile ibadet saatleri, kutsal zaman ve mekânların tespiti gibi birçok alanda astronomi ile ilgili bilgilere ihtiyaç duyulmuştur (Türk, 2010). İhtiyaçlar ve mecburiyet insanoğlunun merak duygusunu harekete geçirmiş ve bu duygu ile şekillenen bilgi birikimi sayesinde yolunu aydınlatımış, keşifler için yeni arayışlara girmiştir. Görüldüğü gibi doğadaki bütün değişimler ve gelişmeler birbirini takip eder ve aynı zamanda birbirini etkiler yapıdadır. İnsandaki değişim ve gelişim eğitimi etkilerken, eğitimde meydana gelen gelişim ve değişimler ise öğrenme öğretme yöntem ve tekniklerini etkiler. Dolayısıyla eğitim durağan bir sistem değil, ihtiyaçlar ve mecburiyetler neticesinde sürekli gelişim ve değişim halinde olan canlı bir yapıdır. Bu canlı yapının içerisinde yer alan bireylerin öğrenme ihtiyaçlarını karşılayabilmek için öğretme-öğrenme ortamlarının yalnızca okul etkinlikleri ile sınırlı tutulmayıp okul dışı mekânların da bu sürece dâhil edilmesi, doğanın bilim ve öğrenme için bir açık alan laboratuarı gibi görülmesi, çocukların gözlem ve araştırmalar yapmaları için fırsatlar sunulması gerekmektedir. Çünkü günümüz bilgi çağında insanoğlunun aklında yine binlerce soru cevaplanmayı beklerken geleceğin teminatı olarak görülen gençlerin araştıran, sorgulayan ve her şeyden önemlisi merak eden ve merakının peşinden giden bireyler olarak yetiştirilmesinde tek mekân olarak okul binalarının görülmemesi, okul dışı ortamlarında bu sürece dâhil edilmesi bir mecburiyettir.

Önder, Arabacı ve Kamaraj (2009) eğitim ve öğretim denildiğinde ilk akla gelen kurum olan okulların artık bu özelliğini yitirdiğini, farklı ortamlarında bu süreçte kullanılması gerektiğini vurgulamıştır. Bu düşünceler ışığında öğrencilerin yaparak yaşayarak öğrendiği, kendi öğrenmelerinden sorumlu olduğu, çevresiyle etkileşim içerisinde araştırmalar yaptığı ve bütün bunların yanı sıra eğlenerek öğrenmenin gerçekleştirildiği ortamlar oluşturulmaya veya bu ortamlara alan gezileri düzenlenmeye çalışılmıştır. Bu ortamların bazıları ABD, Norveç, İsveç, İngiltere ve İskoçya'da Outdoor School Education olarak adlandırılan ortamlarken, bazıları da bilim merkezleri, müzeler, gözlem evleri ve planetaryumlar, hayvanat bahçeleri, botanik bahçeleri ve daha birçok ortam okul dışı eğitim ortamı olarak görülmektedir (Kulalıgil, 2016). Hangi ortam olursa olsun okul dışı eğitim aktivitelerinin okulda eğitimin bir alternatifi olarak değil tam aksine onun bir tamamlayıcısı olarak görülmesi ve sınıfta eğitimle bütünleştirilmiş bir 
eğitim yolu olacak şekilde kullanılması gerekmekte yani formal ve informal eğitim arasındaki bağlantının sağlanması son derece önemli görülmektedir (Eshach, 2007).

Öğrenciler yalnızca formal eğitim faaliyetleri ile insan bilişsel mimarisinin doğası gereği astronomik olayların ve göksel hareketlerin gerçekleşme şeklinin anlamlandırılmasında, mekânsal düşünme ve üç boyutlu görselleştirme becerisinde, gökyüzündeki hareketlerle ilgili karmaşık süreçleri ve bakış açılarını geliştirme konusunda zorlanabilirler. İşte bu noktada mevcut öğretimin yanı sıra planetaryum ile öğretim önemli bir görev üstlenebilir nitekim Ridky (1974) astronomi ve uzay bilimlerinin özellikle planetaryumların simüle etme yeteneği ile bilimi soyut âlemden çıkarıp net ve zevkli bir şekilde hayata geçireceğini ifade etmiştir.

Gelişmiş birçok ülkede, özellikle bilim merkezlerinde, müzelerde ve hatta okul ortamında kullanımı her geçen gün yaygınlaşan planetaryumlar eğitimin her kademesinde başta astronomi olmak üzere edebiyattan coğrafyaya kadar pek çok alanda kullanılabilmektedir (Jettner ve Soroka, 1972). Okul dışı öğrenme ortamlarının eğitim sistemine, ünite kazanımlarına entegrasyonunun sağlanabilmesi de son derece önemlidir (Plummer, 2009). Bu sayede birçok soyut kavramdan oluşan ve anlaşılması üç boyutlu görselleştirme yeteneğine bağlı olan Dünya ve Evren konu alanına ait konular daha eğlenceli, ilgi çekici ve merak uyandırıcı hale getirilebilir (Ertaş ve Şen, 2011).

Yapılan birçok araştırmada, planlı bir şekilde kullanılan okul dışı eğitim ortamlarının öğrencilerde kalıcı öğrenme sağlama, bilgilerin somutlaştırılması, daha çok duyu organına hitap ederek öğrenmeyi hızlandırma, günlük hayatla ilişki kurarak yaparak yaşayarak öğrenme, derse karşı ilgi ve motivasyonu artıırıken kaygıyı azaltma, eğlenceli vakit geçirerek keyif alma, gözlem yapma imkânı sunma, akademik başarıyı artırma, sınıf ortamına taşınamayan konuların daha iyi kavranması için eğitimin kalitesini yükseltme gibi önemli fonksiyonları olduğu ortaya konmuştur (Arıc1, 2013; Bozdoğan, 2008; Çiçek ve Saraç, 2017; Kulalıgil, 2016; Sontay ve Diğerleri, 2016; Türkmen, 2015). Ayrica astronomi ile ilgili konularda eksik bilgilerin ve kavram yanılgılarının giderilmesi ve yeni bilgiler edinilmesi (Arıcı, 2013; Babaoğlu ve Keleş, 2017; Bozdoğan ve Ustaoğlu, 2016; Çepni ve Şenel Çoruhlu, 2014; Türk, 2010) gibi daha birçok yararından bahsedilmektedir. Okul dışı eğitim etkinlikleri ile ilgili yapılan araştırmalar konularına göre incelendiğinde; ne tür ortamların okul dışı öğrenme ortamı olarak görüldüğü (Bostan Sarığlan ve Küçüközer, 2017), öğretmenlerin veya öğretmen adaylarının okul dışı eğitimde hangi ortamları daha fazla tercih ettiği (Selanik Ay ve Erbasan, 2016), bu etkinlikleri hangi amaçları gerçekleştirmek adına yaptıkları (Türkmen, 2015), tercih etme ve etmeme nedenleri (Çiçek ve Saraç, 2017), bu ortamlara yönelik tutum ve özyeterlik algıları (Gürsoy, 2018), müze ve bilim merkezi gezisine yönelik görüşleri (D. Yener, Aksüt, Kiras ve Y. Yener, 2018) araştırılırken, astronomi ile ilgili konularda ise öğrencilerin astronomi konularına yönelik algıları 
ve bu kavramları betimleme şekilleri (Babaoğlu ve Keleş, 2017) ile öğretmenlerin bu konuları işleme şekilleri ve karşılaşılan zorluklar (Yılmaz ve Laçin Şimşek, 2017) ve kavram yanılgılarının belirlenmesi ve giderilmesi (Çepni ve Şenel Çoruhlu, 2014; Özcan ve Yılmaz, 2018) şeklinde araştırmalar bulunmaktadır.

A.B.D., Fransa, Almanya, Japonya, İngiltere ve İtalya başta olmak üzere daha birçok gelişmiş ülkede planetaryumların bir okul dışı eğitim ortamı olarak fen bilimleri öğretiminde sıklıkla kullanıldığı tespit edilmesine rağmen ülkemizde istenilen seviyede kullanılmadığı görülmektedir. Yapılan alan yazın taramasında bu araştırma ile kazandırılmak istenen astronomiye ait soyut konuların somutlaştırılarak daha anlaşılır hale getirilmesi ve üç boyutlu düşünme becerisinin geliştirilmesi gibi kazanımlarda daha çok sanal gerçeklik veya artırılmış gerçeklik teknolojileri ile öğretim çalışmalarının ağırlık kazandığı dikkat çekmektedir. Hem bu kazanımları gerçekleştirmek hem de bütün bu kazanımları okul dışı öğrenme ortamında yaparak yaşayarak ve sanki oradaymış hissi duyarak gerçekleştirmeye imkân tanımak adına planetaryumların yeteri kadar kullanılmadığı görülmektedir. Bu çalışma planetaryumların gerekli hazırlık çalışmaları yapılarak ünite kazanımları ile ilişkilendirilmesi, ders planı ile entegre edilerek kullanılmasına dair alan yazında önemli bir eksikliğin giderilmesi ve benzeri uygulamaların eğitimde kullanımının yaygınlaştırılması açısından önemli görülmektedir.

$\mathrm{Bu}$ amaçlar doğrultusunda araştırmanın problem cümlesi “Okul dışı öğrenme ortamlarından biri olan Planetaryumların Fen Bilimleri dersinde kullanımının 7. sinıf öğrencilerinde akademik başarı, ilgi ve motivasyon düzeyine etkisi nedir?"' olarak belirlenmiştir.

\section{YÖNTEM}

Bu çalışmada, araştırma problemine cevap aramak adına planetaryum gezisi ile öğretimin deney ve kontrol grupları üzerindeki etkisinin ölçülmesi ve grupların karşılaştırılması amacıyla deneysel araştırma yöntemlerinden ön test-son test kontrol gruplu yarı deneysel araştırma deseni kullanılmıştır (Büyüköztürk, 2014, s. 21). Uygulamaya ilişkin öğrenci görüşleri ise nitel tekniklerle elde edilmiştir.

Araştırmanın deneysel desenine ise Tablo 1'de yer verilmiştir. 
Tablo 1.

Araştırmanın Deneysel Deseni

\begin{tabular}{|c|c|c|c|}
\hline Gruplar & Ön Testler & Uygulama & Son Testler \\
\hline \multirow{3}{*}{$\begin{array}{l}\text { Deney } \\
\text { Grubu }\end{array}$} & Akademik Başarı Testi & & Akademik Başarı Testi \\
\hline & $\begin{array}{c}\text { Fen Konularına yönelik } \\
\text { ilgi ölçeği }\end{array}$ & $\begin{array}{l}\text { Planetaryum gezisi } \\
\text { ile öğretim }\end{array}$ & $\begin{array}{c}\text { Fen Konularına yönelik ilgi } \\
\text { ölçeği }\end{array}$ \\
\hline & $\begin{array}{c}\text { Fen Öğrenimine Yönelik } \\
\text { Motivasyon Ölçeği }\end{array}$ & & $\begin{array}{l}\text { Fen Öğrenimine Yönelik } \\
\text { Motivasyon Ölçeği }\end{array}$ \\
\hline \multirow{3}{*}{$\begin{array}{l}\text { Kontrol } \\
\text { Grubu }\end{array}$} & Akademik Başarı Testi & & Akademik Başarı Testi \\
\hline & $\begin{array}{c}\text { Fen Konularına yönelik } \\
\text { ilgi ölçeği }\end{array}$ & $\begin{array}{l}\text { Mevcut programa } \\
\text { uygun öğretim }\end{array}$ & $\begin{array}{c}\text { Fen Konularına yönelik ilgi } \\
\text { ölçeği }\end{array}$ \\
\hline & $\begin{array}{l}\text { Fen Öğrenimine Yönelik } \\
\text { Motivasyon Ölçeği }\end{array}$ & & $\begin{array}{l}\text { Fen Öğrenimine Yönelik } \\
\text { Motivasyon Ölçeği }\end{array}$ \\
\hline
\end{tabular}

Kontrol grubuna uygulanan mevcut programa uygun öğretim kapsamında Güneş Sistemi ve Ötesi ünitesi sınıf ortamında anlatım yöntemi, soru cevap tekniği ve etkileşimli tahta sunuları ile yürütülmüştür. 2 hafta süren bu öğretim toplam 8 ders saatinden oluşmaktadır.

\section{Planetaryum Gezisi İle Öğretim Uygulama Süreci}

Fen bilimleri dersi öğretim programında yer alan 7. Sınıf Dünya ve Evren konu alanına ait 'Yıldız oluşum sürecinin farkına varır, Yıldız kavramını açıklar, Galaksilerin yapısını açıklar ve Evren kavramını açıklar' kazanımlarını gerçekleştirmek için 5 E öğretim modeline göre hazırlanmış olan planetaryum gezi planı uygulanmıştır. Araştırmada 5 E öğretim modelinin tercih edilmesinin sebebi, hem derinleştirme aşamasını içermesi hemde çok fazla basamaktan oluşmaması sebebi ile yapılandırmacı öğrenme kuramına ait ideal bir öğretim yöntemi olarak görülmesidir (Çepni ve Şenel Çoruhlu, 2014).

\section{A- Gezi Öncesi}

\section{1- Eğitimsel hazırlık}

- Planetaryum ile ilgili bizzat gidilerek bilgi alınmıştır (Kapasite, sunumlar, sunumların süresi).

- Gezi Öncesi Görüşme Soruları sınıf ortamında öğrencilere dağıtılarak görüşlerini yazmaları istenmiştir $(20 \mathrm{dk})$.

- Ön Test mahiyetinde Akademik Başarı Testi, Fen Konularına Yönelik İlgi Ölçeği ve Fen Öğrenimine Yönelik Motivasyon Ölçeği uygulanmıştır.

- Öğrenciler için bilgilendirme broşürü hazırlanmıştır.

- Öğrencilerin gezi sırasında cevaplamaları amacıyla çalışma yaprakları hazırlanmıştır.

- 08.30- 08.50 arasında 5 E Modeli Girme Aşaması sınıfta etkileşimli tahta ile gerçekleştirilmiştir.

Öğrencilerin ilgi ve dikkatini konuya çekmek, merak uyandırmak ve planetaryum ile ilgili ön bilgilerini yoklamak adına Şekil 1'de verilen sorular yöneltilmiştir. 


\section{Girme Așaması}
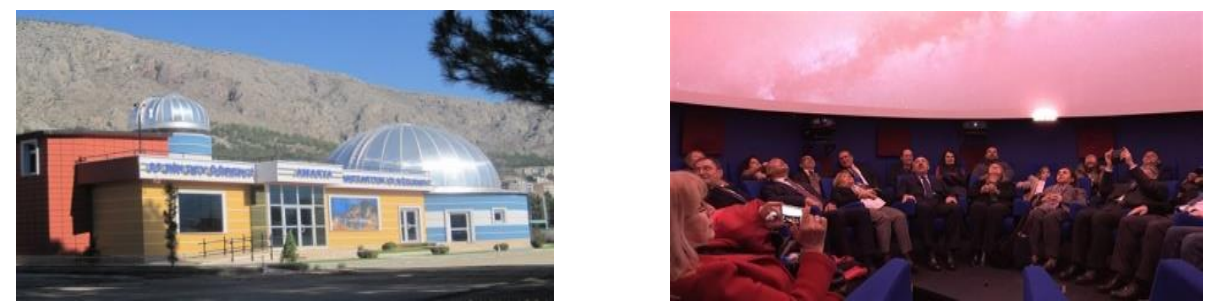

Fotoğraflarda ne görüyorsunuz?

Soldaki fotoğraf bir cami ya da mescide mi ait?

Sağdaki fotoğrafta bulunan insanlar sizce nerede olabilirler? Siz böyle bir yerde bulundunuz mu?

\section{Şekil 1. 5 E Modeli Girme Aşamasının Sınıfta Gerçekleştirilmesi}

\section{2- Bürokratik işlemler}

- Amasya İl Milli Eğitim Müdürlüğü ile irtibata geçilerek 'Planetaryum Ders Etkinliği' için gerekli izinler alınmış ve uygun bir gün için araç tahsisi talep edilmiştir.

- Amasya Planetaryum ve Gözlemevi ile irtibata geçilerek randevu alınmış ve planetaryum yetkililerine çalışma hakkında bilgi verilmiştir.

- Veli İzin Dilekçeleri öğrencilere dağıtılmış, doldurulup imzalanarak getirmeleri sağlanmıştır.

\section{B- Gezi Esnasinda}

- 09.00'da 16 öğrenci ve görevli 2 öğretmen ile planetaryuma hareket edilmiştir.

- Hazırlanan broşürler servislerle planetaryuma doğru giderken öğrencilere dağıtılarak incelemeleri ve gezi ile ilgili ön bilgi sahibi olmaları sağlanmıştır.

- $09.35^{\prime}$ de Amasya planetaryum ve gözlemevine ulaşılmıştır.

- Sunu öncesi rehber eşliğinde planetaryum ile ilgili bilgi verilmiştir (10 dk).

- Önce Uzay Asansörü simülasyonu izlenmiş (21 dk), hemen ardından Karadelikler (Black Holes) adlı simülasyon izlenmiştir (5 dk).

- Sunuların ardından 5 E Modeli Keşfetme aşaması kapsamında öğrenciler planetaryum içerisindeki görseller ve modellerden yararlanarak serbest inceleme yapmış, öğrencilerin gözlemleri ve yaptıkları incelemeler sonucu edindikleri bilgilerle verilen çalışma yapraklarını doldurmaları istenmiştir $(25 \mathrm{dk})$.

- Salona geçilerek 5 E Modeli Açıklama Aşamasında yıldızların özellikleri ve yaşam süreçleri, galaksilerin özellikleri ile uzay ve evren kavramları açıklanmıştır (24 dk).

- Dönüş için hazırlıklar yapılarak 11.00 'da planetaryumdan okula hareket edilerek 11.35 'de okula ulaşılmıştır.

\section{C- Gezi Sonrası}

- 5 E Modeli Derinleştirme Aşaması (İstasyon Tekniği İle Poster Hazırlama) gerçekleştirilmiştir. 
- 5 E Modeli Değerlendirme Aşamasında deney grubuna Gezi Sonrası Görüşme Soruları ve son test mahiyetinde Akademik Başarı Testi, Fen Konularına Yönelik İlgi Ölçeği ve Fen Öğrenimine Yönelik Motivasyon Ölçeği yine sınıf ortamında öğrencilere uygulanmıştır.

- Kontrol grubu öğrencilerinde ise Akademik Başarı Testi, Fen Konularına Yönelik İlgi Ölçeği ve Fen Öğrenimine Yönelik Motivasyon Ölçeği mevcut öğretim tamamlandığında sınıf ortamında öğrencilere uygulanmıştır.

\section{Çalışma Grubu}

Araştırmanın çalışma grubunu; 2019-2020 öğretim yılında Amasya ilinde bulunan bir köy okulunun 7/A ve 7/B şubelerinde yer alan 32 ortaokul 7. sınıf öğrencisi oluşturmaktadır.

\section{Veri Toplama Araçları}

Araştırmada veri toplama araçları olarak; araştırmacı tarafından geliştirilmiş 20 sorudan oluşan Güneş Sistemi ve Ötesi ünitesi ile ilgili Güneş Sistemi Ötesi: Gök Cisimleri Akademik Başarı Testi kullanılmıştır. Testin KR-20 güvenirlik katsayısı 0.87 bulunmuştur. Güvenirlik katsayısının 0.60 ile 0.90 arasında çıkması ölçeğin 'oldukça güvenilir' olduğu şeklinde yorumlanır (Can, 2019, s. 391). Laçin Şimşek ve Nuhoğlu (2009) tarafından 'Tamamen Katılıyorum, Katılıyorum, Kararsızım, Katılmıyorum ve Hiç Katılmıyorum' şeklinde düzenlenmiş 5'li likert tipinde 27 maddeden oluşan ve Cronbach Alpha güvenirlik katsayısı a $=0.79$ olarak hesaplanmış Fen Konularına Yönelik İlgi Ölçeği, Yılmaz ve Huyugüzel Çavaş (2007) tarafından 'Hiç Katılmıyorum, Katılmıyorum, Kararsızım, Katılıyorum ve Tamamen Katılıyorum' şeklinde düzenlenmiş 5'li likert tipinde 33 Maddeden oluşan ve güvenirliği hem eşdeğer yarılar (.89) hem de Cronbach Alpha iç tutarlılı̆̆ı (.87) ile hesaplanmış Fen Öğrenimine Yönelik Motivasyon Ölçeği, planetaryum ile öğretime yönelik öğrenci görüşlerini belirleyebilmek adına yine araştırmacı tarafından alan uzmanı akademisyen görüşü alınarak hazırlanmış olan 4 sorudan oluşan gezi öncesi ve 5 sorudan oluşan gezi sonrası yarı yapılandırılmış görüşme formları kullanılmıştır.

\section{Gezi öncesi görüşme soruları}

1. Planetaryum hakkında herhangi bir bilgin var mı? Eğer bilgin varsa bu bilgiye nerden ulaştın, açıklar mısın?

2. Daha önce hiç planetaryuma gittin mi?

Evet ise; Nasıl bir yer olduğunu tarif eder misin? Hayır, ise; Nasıl bir yer olabileceğini düşünüyorsun?

3. Fen bilimleri dersi kapsamında gerçekleştirilen planetaryum gezisinden beklentilerin nelerdir, açıklar mısın?

4. Planetaryum gezisinin fen dersine nasıl bir etkisinin olacağını düşünüyorsun? 


\section{Gezi sonrası görüş̧me soruları}

1. Gerçekleştirdiğimiz planetaryum gezisi beklentilerini karşıladı $\mathrm{ml}$, hayalindeki gibi miydi? Beğendiğin ve beğenmediğin noktaların neler olduğunu açıklar mısın?

2. Planetaryum gezisi fen dersine yönelik duygu ve düşüncelerini nasıl etkiledi, sana bir faydası olup olmadığını açıklar mısın?

3. Planetaryum gezisinde öğrendikleriniz ile okulda öğrendikleriniz arasında farklılıklar var midır, açıklar mısın?

4. Güneş Sistemi ve Ötesi: Gök Cisimleri ünitesi ile ilgili planetaryumda neler öğrendiniz, açıklar misin?

5. Fen dersinde bu tür gezilerin yapılması hakkındaki görüşlerin nelerdir?

\section{Veri Analizi}

Araştırmada deney ve kontrol gruplarının akademik başarı, ilgi ve motivasyon gibi belirlenen değişkenler yönünden puanları arasındaki farklılı̆̆ı belirlemek amacıyla SPSS 22 programı kullanılarak Shapiro-Wilk normallik testi ve normalliğin sağlanması durumuna göre Bağımsız Örneklem t-testi ile istatistiksel analizler yapılmıştır. Can (2019, s.126) normal dağılım gösteren verilerin istatistiksel hesaplamalarında parametrik testler kullanılabileceğini belirtmiştir.

7.sınıf fen bilimleri dersi Güneş Sistemi ve Ötesi ünitesi ile ilgili hazırlanan akademik başarı testi ile Fen konularına yönelik ilgi ölçeği ve Fen öğrenimine yönelik motivasyon ölçeği deney ve kontrol grubu öğrencilerine ön test ve son test olarak ayrı ayrı uygulanmıştır. Verilerin SPSS programına girilmesi sonrasında gerekli incelemeler yapıldıktan sonra (kayıp veri, yanlış veri) verilerin normal dağılım gösterip göstermediğine Shapiro-Wilk analizi ile bakılmış, yapılan analiz sonucunda elde edilen ve (Sig.) ile gösterilen $p$ değerinin .05 ten büyük olmasının puanların normal dağılım gösterdiği şeklinde yorumlanabileceğini belirtmiştir (Can, 2019, s. 89).

Planetaryum ile öğretime yönelik öğrenci görüşlerini belirlemek için araştırmacı tarafından hazırlanan yarı yapılandırılmış görüşme sorularının analizinde ise Gezi Öncesi ve Gezi Sonrası Görüşme Soruları ile elde edilen verilerin içerik analizleri yapılmıştır. Öncelikle alan uzmanı akademisyen görüşüne başvurularak görüşme sorularını en iyi yansıtacak olan genel temalar belirlenmiştir. Daha sonra iki fen bilimleri ve bir Türkçe öğretmeni tarafından her bir soruya verilen cevaplar ayrı ayrı okunarak incelenmiş ve temaları yansıtan kodlar oluşturulmuştur. En son aşamada ise her bir öğretmenin görüşleri üzerinde tartış1lıp görüş birliği sağlanarak kodlar yeniden düzenlenmiş ve kodların frekans (f) dağılımları tablolar halinde sunulmuştur. Tabloların alt kısmında gerekli açıklamalar yapılmış ve kodlarla ilişkili öğrenci ifadelerine yer verilmiştir. Öğrenci ifadelerine yer verilirken $\mathrm{k}$ ız öğrenciler $K_{1}{ }^{\prime}$ den $K_{6}{ }^{\prime}$ ya, erkek öğrenciler $\mathrm{E}_{1}{ }^{\prime}$ den $\mathrm{E}_{10}{ }^{\prime} \mathrm{a}$ kadar adlandırılmıştır. 


\section{BULGULAR}

Bu bölümde öncelikle değişkenlerin normal dağılıma uygunluğunu test etmek için Shapiro - Wilk normallik testi uygulanmış, ardından araştırma sorularına ilişkin bulgulara yer verilmiştir.

\section{Araştırmada Kullanılan Ölçeklere İlişskin Normallik Testi}

Araştırmada kullanılan Akademik başarı testi, Fen Konularına Yönelik İlgi Ölçeği ve Fen Öğrenimine Yönelik Motivasyon Ölçeğine ilişkin Shapiro-Wilk normallik testi sonuçları Tablo 2'de gösterilmiştir.

Tablo 2.

Araştırmada Kullanılan Ölçeklere İlişkin Ön Test-Son Test Deney ve Kontrol Gruplu Shapiro-Wilk Normal Dağılım Test Sonuçları

\begin{tabular}{ccc}
\hline Uygulanan Testler & & Shapiro-Wilk \\
\hline \multirow{2}{*}{ Akademik Başarı Testi } & Ön test & .27 \\
\multirow{2}{*}{ İlgi Ölçeği } & Son test & .82 \\
& Ön test & .46 \\
Motivasyon Ölçeği & Son test & .11 \\
& Ön test & .40 \\
& Son test & .22 \\
\hline
\end{tabular}

Tablo 2 incelendiğinde değişkenlerin normal dağılım gösterdiği görülmektedir ( $p>.05$ ). Değişkenlerin normal dağılım göstermesi ile birlikte verilerin karşılaştırılmasında bağımsız örneklem t-testi gibi parametrik bir yöntem kullanılmıştır.

\section{Ön test Puanlarına İlişkin Bulgular}

Mevcut öğretim programına tabi tutulan kontrol grubu ile planetaryumla öğretimin uygulandığı deney grubu öğrencilerinin Akademik Başarı Testi, İlgi ve Motivasyon Ölçeği ön test puanları arasında istatistiksel olarak anlamlı bir fark olup olmadığına ilişkin sonuçlar Tablo 3'te gösterilmiştir.

Tablo 3.

Deney ve Kontrol Grubu Öğrencilerinin Akademik Başarı Testi, Fen Konularına Yönelik İlgi Ölçeği ve Fen Öğrenimine Yönelik Motivasyon Ölçeği Ön Test Puanlarına İlişkin Bă̆ımsız Örneklem t- Testi Sonuçlar

\begin{tabular}{llcccccc}
\hline \multicolumn{2}{c}{ Uygulanan Testler } & $\mathbf{n}$ & $\overline{\mathbf{x}}$ & $\mathbf{S}$ & $\mathbf{S d}$ & $\mathbf{t}$ & $\mathbf{p}$ \\
\hline \multirow{2}{*}{ Akademik Başarı } & Deney Grubu & 16 & 4.94 & 2.21 & 30 & 0.17 & 0.87 \\
& Kontrol Grubu & 16 & 5.06 & 2.05 & & & \\
\hline \multirow{2}{*}{ İlgi } & Deney Grubu & 16 & 106.00 & 10.89 & 30 & 0.63 & 0.53 \\
& Kontrol Grubu & 16 & 108.81 & 14.03 & & & \\
\hline \multirow{2}{*}{ Motivasyon } & Deney Grubu & 16 & 108.50 & 15.07 & 30 & 1.46 & 0.16 \\
& Kontrol Grubu & 16 & 117.69 & 20.15 & & & \\
\hline
\end{tabular}

$p>0.05$ 
Tablo 3 incelendiğinde deney ve kontrol grubu öğrencilerinin Akademik başarı testi, İlgi ve Motivasyon Ölçeği ön test puanları arasında istatistiksel olarak anlamlı bir fark olmadığı görülmüştür ( $p>0.05$ ). Bu bulgu, grupların uygulama öncesinde akademik başarı, ilgi ve motivasyon gibi değişkenler açısından birbirine denk (benzer) olduğu şeklinde yorumlanmaktadır.

\section{Son test Puanlarına İlişkin Bulgular}

\section{Akademik Başarı Testi Son Test Puanları Karşılaştırılması}

Akademik başarı testi ön test puanları arasında istatistiksel olarak anlamlı bir fark olup olmadığına ilişkin sonuçlar Tablo 4'de gösterilmiştir.

Tablo 4.

Deney ve Kontrol Grubu Öğrencilerinin Akademik Başarı Testi Son Test Puanları Karşılaştırllmasına İlişkin Bağımsız Örneklem t-Testi Sonuçları

\begin{tabular}{lcccccc}
\hline Grup & $\mathbf{n}$ & $\overline{\mathbf{X}}$ & $\mathbf{S}$ & $\mathbf{S d}$ & $\mathbf{t}$ & $\mathbf{p}$ \\
\hline Deney Grubu & 16 & 13.31 & 3.26 & 30 & 2.30 & .029 \\
Kontrol Grubu & 16 & 10.56 & 3.50 & & &
\end{tabular}

$\overline{p<.05}$

Tablo 4 incelendiğinde grupların akademik başarı testi son test puanlarında istatistiksel olarak deney grubu lehine anlamlı bir fark olduğu görülmüştür [ $t(30)=2.30, p<.05]$. Bu bulgu grupların Güneş Sistemi ve Ötesi ünitesine ilişkin başarılarında, planetaryumlara düzenlenen planlı bir gezi ile öğretimin kontrol grubuna uygulanan mevcut öğretimden daha etkili olduğu şeklinde yorumlanmaktadır.

\section{Fen Konularına Yönelik İlgi Ölçeği Son Test Puanları Karşılaştırılması}

Deney ve kontrol grubu öğrencilerinin ilgi ölçeği son test puanları ortalamalarının karşılaştırılmasına ilişkin yapılan bağımsız örneklemler t-testi sonuçları Tablo 5'de gösterilmiştir.

Tablo 5.

Deney ve Kontrol Grubu Öğrencilerinin Fen Konularnna Yönelik İlgi Ölçeği Son Test Puanlarn Karşılaştırılmasına İlişkin Bă̆ımsız Örneklem t-Testi Sonuçları

\begin{tabular}{lcccccc}
\hline Grup & $\mathbf{n}$ & $\overline{\mathbf{X}}$ & $\mathbf{S}$ & $\mathbf{S d}$ & $\mathbf{t}$ & $\mathbf{p}$ \\
\hline Deney Grubu & 16 & 117.81 & 10.53 & 30 & 2.069 & .047 \\
Kontrol Grubu & 16 & 109.25 & 12.77 & & & \\
\hline
\end{tabular}
$\overline{p<.05}$

Tablo 5 incelendiğinde grupların ilgi ölçeği son test puanlarında istatistiksel olarak deney grubu lehine anlamlı bir fark olduğu görülmüştür [t(30)=2.069, $p<.05]$. Bu bulgu, öğrencilerin fen konularına yönelik ilgilerinin artmasında planetaryuma düzenlenen gezi ile öğretimin mevcut öğretimden daha etkili olduğu şeklinde yorumlanmaktadır. 


\section{Fen Öğrenimine Yönelik Motivasyon Ölçeği Son Test Puanları Karşılaştırılması}

Deney ve kontrol grubu öğrencilerinin motivasyon ölçeği son test puanları ortalamalarının karşılaştırılmasına ilişkin yapılan bağımsız örneklemler t-testi sonuçları Tablo 6' da gösterilmiştir.

Tablo 6.

Deney ve Kontrol Grubu Öğrencilerinin Fen Öğrenimine Yönelik Motivasyon Ölçeği Son Test Puanlarn Karşılaştırılmasına İlişkin Bă̆ımsı Örneklem t-Testi Sonuçları

\begin{tabular}{lcccccc}
\hline Grup & $\mathbf{n}$ & $\overline{\mathbf{X}}$ & $\mathbf{S}$ & $\mathbf{S d}$ & $\mathbf{t}$ & $\mathbf{p}$ \\
\hline Deney Grubu & 16 & 138.25 & 9.44 & 30 & 2.831 & .008 \\
Kontrol Grubu & 16 & 123.75 & 18.18 & & & \\
\hline
\end{tabular}
$\overline{p<.05}$

Tablo 6 incelendiğinde, grupların motivasyon ölçeği son test puanlarında istatistiksel olarak deney grubu lehine anlamlı bir fark olduğu görülmüştür [t(30)=2.831, $p<.05]$. Bu bulgu, öğrencilerin Fen öğrenimine yönelik motivasyonlarının artmasında planetaryuma düzenlenen gezi ile öğretimin mevcut öğretimden daha etkili olduğu şeklinde yorumlanmaktadır.

\section{Öğrencilerin Gezi Öncesi Düşüncelerine İlişkin Bulgular}

Öğrencilerin Planetaryum gezisi öncesi görüşme sorularına verdikleri cevaplar incelenmiş ve Tablo 7'de sunulmuştur.

Tablo 7.

Gezi Öncesine İlişkin Öğrenci Görüşleri

\begin{tabular}{|c|c|c|c|c|c|}
\hline Tema & Kod & Frekans(f) & Tema & Kod & Frekans(f) \\
\hline $\begin{array}{l}\text { Bilgi } \\
\text { sahibi } \\
\text { olma }\end{array}$ & $\begin{array}{l}\text { Evet } \\
\text { Hayır }\end{array}$ & $\begin{array}{c}0 \\
16\end{array}$ & $\begin{array}{l}\text { Geziden } \\
\text { beklentile } \\
\mathrm{r}\end{array}$ & $\begin{array}{l}\text { Öğrenme- } \\
\text { Keşfetme } \\
\text { Eğlence } \\
\text { Zekâ geliştirme }\end{array}$ & $\begin{array}{l}4 \\
5 \\
1\end{array}$ \\
\hline Ortam & $\begin{array}{c}\text { Gitmeyen } \\
\text { Tarihi eser ve } \\
\text { Müze } \\
\text { Gözlem yeri } \\
\text { Güneş Sistemi } \\
\text { Eğlenceli } \\
\text { Fen dersi ile ilgili }\end{array}$ & $\begin{array}{l}16 \\
2 \\
4 \\
1 \\
6 \\
1\end{array}$ & & $\begin{array}{l}\text { Merak uyandırma } \\
\text { Gökyüzünü } \\
\text { izleme } \\
\text { Deney, gözlem, } \\
\text { sunum } \\
\text { Bilmiyorum }\end{array}$ & $\begin{array}{l}3 \\
1 \\
3 \\
1\end{array}$ \\
\hline & Akvaryum & 1 & $\begin{array}{l}\text { Fen } \\
\text { dersine } \\
\text { olas1 etki }\end{array}$ & $\begin{array}{l}\text { Anlamlı öğrenme } \\
\text { Eğlenceli Ders } \\
\text { Derse yardımc1 } \\
\text { olma } \\
\text { Bilmiyorum }\end{array}$ & $\begin{array}{l}2 \\
5 \\
5 \\
4\end{array}$ \\
\hline
\end{tabular}

Tablo 7 incelendiğinde planetaryum gezisine katılan 16 öğrencinin tamamının daha öncesinde Planetaryum ile ilgili herhangi bir bilgiye sahip olmadıkları görülmektedir. Öğrencilerin büyük çoğunluğu planetaryumun eğlenceli veya gözlem yapılan bir yer olabileceği yönünde tahminde bulunmaktadır. Öğrenciler; 'Bence güzel bir yerdir, eğlenceli bir yerdir ( $\left.E_{7}\right)$ ', 'Ben orada bir şeylerin gözlemlendiğini düşünüyorum $\left(K_{6}\right)$, 'Teleskop vardır oradan gökyüzündeki gökcisimlerini izleyebiliriz $\left(\mathrm{K}_{2}\right)^{\prime}$,' 'Bir tane ama koskocaman bir akvaryum ve akvaryumun içinde deniz 
hayvanları var diye düşünüyorum $\left(E_{8}\right)$ ', 'Tarihi eser olabilir, müze gibi olabilir $\left(K_{4}\right)$ ' şeklinde ifade etmektedir. Öğrencilerin eğlence, öğrenme-keşfetme ve merak uyandırma gibi beklentilerin daha fazla olduğu görülmektedir. Öğrencilerin yaptığı yorumlardan bazıları; 'Güzel bir yer olması, eğlenceli ve zekâ geliştirmesi olabilir $\left(K_{4}\right)^{\prime}$, 'Yeni yeni şeyler öğrenmek, planetaryum nasıl bir yer orayı keşfetmek istiyorum (E9)', ‘Güzel bir sunum ve güzel bir gün geçirme $\left(E_{2}\right)$ ' şeklindedir. Öğrencilerin fen dersinin eğlenceli olacağı, derse yardımcı olacağı cevaplarını daha çok verdikleri görülmektedir. Öğrenciler; 'Ĕ̆ger fen dersi ile ilgili olan şeyleri öğrenirsem ders daha iyi geçer $\left(K_{6}\right)$ ', 'İyi bir etkisi olabilir, sevinçli ve eğlenceli olabilir $\left(K_{4}\right)^{\prime}$ cevabını vermiştir.

\section{Gezi Sonrası Düşüncelerine İlişkin Bulgular}

Öğrencilerin planetaryum gezisi sonrası görüşme sorularına verdikleri cevaplar incelenmiş ve Tablo 8 ve Tablo 9'da sunulmuştur.

Tablo 8.

Gezi Sonrasına İlişkin Öğrenci Görüşleri

\begin{tabular}{llc}
\hline Tema & Kod & f \\
\hline \multirow{3}{*}{ Beklentilerin karşılanma düzeyi } & Evet & 13 \\
& Hayır & 0 \\
& Kismen & 3 \\
\hline \multirow{3}{*}{ Beğenilen noktalar } & Uzayda gibi hissetme & 7 \\
& Kubbe şeklinde yapı & 6 \\
& Yatar şekilde izleme & 3 \\
& Derse katacağı kalıcı bilgiler & 2 \\
& Yeni bilgiler edinme & 1 \\
\hline \multirow{2}{*}{ Beğenilmeyen noktalar } & Görüntünün anlaşılır & 1 \\
\hline \multirow{2}{*}{ Fen dersine yönelik duygu ve düşünce } & olmaması & 8 \\
değişimi & Karmaşık gelen konuların & \multirow{2}{*}{ Gezi ile öğretim ve mevcut öğretim arasındaki } \\
farklar & daha anlaşılır olması & 7 \\
\hline \multirow{2}{*}{ Ünite ile ilgili kazanımlar } & İgi ve merak artışı & 10 \\
& Eğlenceli ders & 12 \\
\hline \multirow{2}{*}{ Bu tür geziler ile ilgili görüşler } & Kalıı öğrenme & 10 \\
& Yyldıların oluşumu & 9 \\
\hline
\end{tabular}

Tablo 9 incelendiğinde öğrencilerin gezi ile ilgili beklentilerinin karşılanma düzeyinin büyük oranda sağlandığı görülmektedir. En beğenilen noktalar ile ilgili; uzayda gibi hissetme, kubbe şeklindeki tavan ve sunuların yatar pozisyonda izlenmesi şeklinde yorumlar yapılırken, beğenilmeyen noktalar ile ilgili yalnızca bir öğrenci tarafından görüntünün daha net ve anlaşılır olması gerektiği ifade edilmektedir. Beklentilerin karşılanma düzeyi ile beğenilen ve beğenilmeyen noktalar temalarına yönelik öğrenci ifadelerinden birkaçı şunlardır; 'Beklentilerimi karşıladı, Dersimizi o kubbe şeklindeki planetaryumda işlesek keşke $\left(E_{2}\right)^{\prime}$, 'Evet beklentilerimi karşıladl, Kendimi uzayda gibi hissettim, meteor taşlar falan üzerime geldi $\left(K_{4}\right)^{\prime}$. 'Biraz karşıladı, görüntü biraz daha anlaşılı olabilir, uzayda gibi kendimi hissettim $\left(K_{3}\right)^{\prime}$. 
Planetaryum gezisi fen dersine yönelik duygu ve düşüncelerini nasıl etkiledi, sana bir faydası olup olmadığını açıklar mısın? sorusu şeklinde yöneltilen ve ‘Fen dersine yönelik duygu ve düşünce değişimi' temasına göre öğrencilerin büyük çoğunlu kendilerine karmaşık gelen, daha fazla soyut konuların yer aldığı bu ünitenin planetaryum gezisi ile daha anlaşılır olduğu, bu konulara duydukları ilgi ve merakın daha da arttığı belirtilmektedir. Öğrencilerin verdiği cevaplardan birkaçı şunlardır; 'Burada daha iyi anladım (E$\left.E_{1}\right)$ ', 'Gözümde canlandırmam daha kolay oldu $\left(K_{2}\right)^{\prime}$, 'Şimdi uzayı daha çok merak etmeye başladım $\left(E_{4}\right)^{\prime}$.

Planetaryum gezisinde öğrendikleriniz ile okulda öğrendikleriniz arasında farklılıklar var mıdır, açıklar mısın? sorusu şeklinde yöneltilen ve ‘Gezi ile öğretim ve mevcut öğretim arasındaki farklar' temasına göre planetaryum gezisi ile entegre edilmiş öğretimin kalıcı öğrenmeleri sağlama ve dersi eğlenceli hale getirme konusunda üstün olduğu ifade edilmektedir. Gezi ile öğretim ile okuldaki mevcut öğretim arasındaki farklarla ilgili öğrencilerin verdiği cevaplardan birkaçı şunlardır; 'Çok eğlendim, keşke her ders böyle olsa $\left(K_{5}\right)^{\prime}$, 'Sanki gökyüzünde uçuyormuş gibi hissetmek çok eğlenceliydi $\left(K_{2}\right)$ ', 'Burada gördüklerimi kolay kolay unutmam $\left(E_{5}\right)$ ' şeklindedir.

Güneş Sistemi ve Ötesi: Gök Cisimleri ünitesi ile ilgili planetaryumda neler öğrendiniz, açıklar mısın? sorusu 'Ünite ile ilgili kazanımlar' temasına göre öğrenciler yıldızların yaşamı, karadelikler ve galaksilerin daha iyi anlaşıldığı şeklinde görüşler belirtmektedir. Öğrenci görüşlerinden bazıları şu şekildedir; 'Bir yıldızın oluşurken geçtiği yolları izledim (E5)', 'Yıldızlarda insanlar gibi doğar, yaşar ve ölürlermiş onu öğrendim $\left(K_{4}\right)$, 'Karadeliklerin her şeyi yuttuğunu gördüm $\left(E_{3}\right)^{\prime}$.

Son olarak öğrencilere fen dersinde bu tür gezilerin yapılması hakkındaki görüşlerin nelerdir? sorusu ve 'Bu tür geziler ile ilgili görüşler' temasına göre öğrenciler bu ve benzeri etkinliklerin çok eğlenceli ve öğretici olacağı yönünde görüşler belirtilmektedir. Öğrenci görüşlerinden bazıları şu şekildedir; 'Keşke hep böyle ders işlesek ( $\left.E_{3}\right)^{\prime}$ ', 'Çok eğlendim, çok güzel şeyler öğrendim $\left(K_{4}\right)$ '. 'Bence her sene yapılsın, böyle çok eğlenceli $\left(K_{1}\right)$ '. 'Keşke tüm dersler böyle olsa $\left(K_{2}\right)$ '.

\section{TARTIŞMA}

\section{Öğrencilerin Akademik Başarı Düzeylerinin Değerlendirilmesi}

Planetaryum gezisi ile öğretimin uygulandığı deney grubu ile mevcut öğretimin uygulandığı kontrol grubunun ön test ve son test puanları incelenerek öğrencilerin akademik başarı düzeyleri belirlenmiştir.

Deney ve kontrol gruplarının uygulama öncesinde akademik başarı testi puanları arasında anlamlı bir fark bulunmamış yani grupların birbirine denk (benzer) olduğu görülmüştür $(p=0.87)$. Grupların son test puanları incelendiğinde ise her ikisinde de artış olduğu gözlenmiş fakat deney grubu lehinde anlamlı bir fark tespit edilmiştir ( $\mathrm{p}=0.03)$. Bu bulgu, planetaryum gezisi ile entegre edilmiş öğretimin öğrencilerin akademik başarılarını mevcut öğretime oranla 
daha fazla artırdı̆̆ını göstermektedir. Bu durumun nedeni olarak, Güneş sistemi ve ötesi ünitesinde bulunan soyut konuların somutlaştırılması, zihinde canlandırılarak anlamlandırılmasında planetaryum ortamının sinıf ortamina oranla daha etkili olması gösterilebilir. Gerek diğer sınıf dışı eğitim ortamlarının gerekse planetaryumların fen bilimleri öğretimindeki etkililiği ile ilgili alan yazındaki bulgular bu sonucu destekler niteliktedir. Mallon ve Bruce (1982) tarafından geleneksel program ile planetaryum programının ilkokul öğrencileri üzerindeki etkisi karşılaştırılarak etkinlik odaklı planetaryum programının daha üstün olduğu, Palmer (2007) öğrencilerde Ay'ın evreleri ve Güneş tutulması gibi konularda öğrenmeyi önemli ölçüde artırdığı, Plummer (2009) tarafından planetaryumda gerçekleştirilen kısa müdahalelerin bile fen kavramlarının anlaşılmasını artırdığı, Yu ve diğerleri (2015) planetaryumda gerçekleştirilen etkinliklerin öğrenci başarısını artırdığı ve uzun süre koruduğu, Chastenay (2016) planetaryum oturumundan sonra öğrencilerin Ay'ın evrelerini daha iyi anladığı, Bodur ve Yıldırım (2018) bilim merkezindeki planetaryum etkinliklerinin öğrencilerin gök cisimleri ve uzayla ilgili konulardaki soyut kavramları öğrenme düzeylerini artırdığı, Gülen (2018) planetaryum etkinliklerinin 7.sınıf ve 8.sınıf öğrencilerinde akademik başarıyı artırdığı ifade edilmektedir.

Genel olarak, planetaryum özelinde çalışmalar çok fazla olmasa da sınıf dışı öğrenme ortamları üzerine yapılan çalışmalar, sınıf dışı öğrenme ortamlarının öğrencilerde akademik başarıyı artırdığını destekler niteliktedir (Arıcı, 2013; Bozdoğan ve Yalçın, 2006; Kulalıgil, 2016).

\section{Öğrencilerin Fen Konularına Yönelik İlgi Düzeylerinin Değerlendirilmesi}

Fen Konularına Yönelik İlgi Ölçeği kullanılarak deney grubu ile kontrol grubunun ön test ve son test puanları incelenmiş ve fen konularına yönelik ilgi düzeyleri belirlenmiştir.

Araştırmanın ikinci alt problemine ait ilgi ölçeği ile ilgili bulgulara bakıldığında deney ve kontrol gruplarının uygulama öncesinde fen konularına yönelik ilgi düzeylerinin birbirinden farklı olmadığı̆, grupların birbirine denk (benzer) olduğu görülmektedir ( $p=0.53)$. Uygulama sonrasında yapılan son test puanlarına bakıldığında ise deney grubu lehine anlamlı bir fark olduğu sonucuna ulaşılmıştır ( $p=0.04)$. Bu sonuç planetaryum gezisi ile entegre edilmiş öğretimin öğrencilerin fen konularına yönelik ilgi düzeylerini mevcut öğretime oranla daha fazla artırdığını göstermektedir. Bunun nedeni olarak nitel verilerin toplanmasında kullanılan Gezi Sonrası Görüşme Sorularına verilen cevaplarda olduğu gibi planetaryum gezisinin öğrenciler tarafından eğlenceli, ilgi çekici ve merak uyandırıcı bulunması, fen derslerini imkanlar dahilinde bu ve benzeri sınıf dışı etkinliklerle geçirme isteği gösterilebilir. Alan yazında yapılan çalışmalar incelendiğinde planetaryumların öğrencilerde fen konularına yönelik ilgi düzeylerini artırdığı yönündeki sonucu destekler niteliktedir (Bahali, 2014; Bozdoğan ve Yalçın, 2006; Bozdoğan, 2007; Jarvis ve Pell, 2005; Petrie, 2013). 


\section{Öğrencilerin Fen Öğrenimine Yönelik Motivasyon Düzeylerinin Değerlendirilmesi}

Fen Öğrenimine Yönelik Motivasyon Ölçeği kullanılarak deney grubu ile kontrol grubunun ön test ve son test puanları incelenmiş ve fen öğrenimine yönelik motivasyon düzeyleri belirlenmiştir.

Araştırmanın üçüncü alt problemine ait motivasyon ölçeği ile ilgili bulgulara bakıldığında deney ve kontrol gruplarının uygulama öncesinde fen öğrenimine yönelik motivasyon düzeylerinin birbirinden farklı olmadığı, grupların birbirine denk (benzer) olduğu görülmektedir $(p=0.16)$. Uygulama sonrasında yapılan son test puanlarına bakıldığında ise deney grubu lehine anlamlı bir fark olduğu sonucuna ulaşılmıştır $(\mathrm{p}=0.01)$. Bu sonuç planetaryum gezisi ile entegre edilmiş öğretimin öğrencilerin fen öğrenimine yönelik motivasyonlarını mevcut öğretime oranla daha fazla artırdığını göstermektedir. Yılmaz ve Huyugüzel Çavaş (2007) motivasyonu, insan organizmasını davranışa iten, davranışları yönlendiren ve onların devam etmesini sağlayan duyuşsal bir faktör olarak tanımlamışlardır. O halde öğrencilerin hem ilgi düzeylerini artıran hem de kaygı duymalarını gerektirmeyip eğlenceli bulunan planetaryum gezisi ile öğretimin öğrencilerde istendik davranışı sergilemeye teşvik ettiği düşünülebilir. Alan yazında yapılan çalışmalar incelendiğinde öğretmen adaylarının görüşlerinden yola çıkarak planetaryumların öğrencilerde fen öğrenimine yönelik motivasyonu artırdığı yönündeki sonucu destekler niteliktedir. Bozdoğan ve Ustaoğlu (2016) planetaryumların derse karşı ilgi ve motivasyonu artıran etkileyici bir ortam olarak nitelendirmişlerdir. Bunun dışında planetaryumların fen dersine yönelik motivasyona etkisi ile ilgili bir çalışmaya rastlanılmamakla birlikte genel olarak sınıf dışı öğrenme ortamlarının öğrencilerin motivasyonlarını artırdığını ifade eden ve bu çalışma bulgularını destekler nitelikte çalışmalar bulunmaktadır (Çankaya ve Girgin, 2018; Kulalıgil, 2016; Ramey Gassert, 1997).

\section{Öğrencilerin Gezi Öncesi ve Gezi Sonrası Düşüncelerinin Değerlendirilmesi}

Araştırmanın dördüncü alt problemine ait gezi öncesi ve gezi sonrası görüşme soruları ile ilgili bulgulara bakıldığında, öğrencilere uygulanan gezi öncesi görüşme sorularına verilen cevaplara göre öğrencilerin hiçbirinin gezi öncesi planetaryum ile ilgili bilgi sahibi olmadığ görülmüştür. Planetaryumun bir gözlem yeri, eğlenceli bir yer veya içerisinde tarihi eserlerin olduğu müze benzeri bir mekan olabileceği şeklinde tahminler yürütülmüş, planetaryum gezisinden yeni şeyler öğrenme, keşfetme, eğlenceli vakit geçirme ve merak duyma gibi beklentilere sahip olunduğu ifade edilmiş ve son olarak planetaryum gezisi ile birleştirilen fen dersinin daha eğlenceli olacağı, bu gezinin derse yardımcı olacağı ve anlamlı öğrenme sağlayacağı belirtilmiştir (Tablo 7). Bu beklenti ve tahminler 1şı̆̆ında gerçekleştirilen planetaryum gezisi ile öğretim sonucunda öğrencilerle gezi sonrası görüşmeler gerçekleştirilmiştir. Öğrencilere uygulanan gezi sonrası görüşme sorularına verilen cevaplara göre öğrencilerin büyük çoğunluğunda beklentilerin karşılandı̆̆ı, en beğenilen noktaların 
kendini uzayda gibi hissetme, kubbe şeklinde yapı ve yatar pozisyonda sunuları izleme şeklinde görüş bildirildiği, planetaryum gezisi ile bütünleştirilen öğretimin fen dersine yönelik ilgi ve merak artışına sebep olduğu, karmaşık gelen konuların daha anlaşılır hale geldiği görülmüştür (Tablo 8). Alanyazındaki bulgular ile çalışma sonuçları benzerlik göstermektedir (Bahali, 2014; Bozdoğan ve Ustaoğlu, 2016; Plummer ve diğerleri, 2014; Ridky, 1974; Türk, 2010). Planetaryum gezisi ile öğretimin okulda gerçekleştirilen öğretime göre daha eğlenceli, öğretici olduğu ve kalıcı öğrenmeler sağladığı görülmüştür (Tablo 9). Çalışma sonuçları alanyazın ile örtüşmektedir (Bozdoğan ve Ustaoğlu, 2016; Sontay ve diğerleri, 2016).

\section{SONUÇ}

Günümüz eğitim sisteminde öğrencilerin öğrenme ihtiyaçlarını karşılayabilmek adına geleneksel öğretim yöntem ve tekniklerinin yanı sıra öğrencilerin doğasına uygun, yaparak yaşayarak öğrenmeyi gerçekleştirecek, merak ve keşfetme duygularını harekete geçirerek soyut olanı somutlaştıracak ve hatta sanki oradaymış hissi uyandıracak okul dışı öğrenme ortalarına da ihtiyaç duyulmaktadır. Yapılan çalışma ile bu ihtiyacın giderilmesi ve bahsedilen kazanımların gerçekleştirilmesinde planetaryumun önemli bir görev üstlenebileceği belirlenmiştir.

Sınıf ortamında yapılan mevcut öğretimle karşılaştırıldığında planetaryum gezisi ile entegre edilmiş öğretimin, öğrencilerin Güneş sistemi ve ötesi ünitesindeki akademik başarısını artırdığı görülmüştür. Nitel verilerin toplanmasında kullanılan gezi sonrası görüşme sorularına verilen cevaplar ile fen konularına yönelik ilgi ölçeği sonuçları birbirini destekler nitelikte planetaryum gezisinin öğrenciler tarafından eğlenceli, merak uyandırıcı bulunduğu ve fen konularına yönelik ilgi düzeylerinde anlamlı bir artışa sebep olduğu tespit edilmiştir. Yine planetaryum gezisi ile entegre edilmiş öğretimin öğrencilerin fen öğrenimine yönelik motivasyonlarını mevcut öğretime oranla daha fazla artırdığı görülmüştür.

Başlangıçta planetaryum ortamı ile ilgili hiçbir bilgiye sahip olmayan öğrencilerde bu ortama dair farkındalık oluştuğu belirlenmiştir. Beklentilerin büyük oranda karşılandığı, gerek planetaryumun mimari yapısı gerekse ses ve görüntü efektleriyle desteklenen sunuların öğrencilerde sanki oradaymış hissi uyandırması sebebiyle okulda gerçekleştirilen öğretime göre daha eğlenceli, öğretici ve karmaşık gelen konuların daha anlaşılır hale geldiği tespit edilmiştir.

\section{ÖNERILER}

1. Öğrencilerin yapılacak okul dışı eğitim faaliyetini sadece gezme olarak değerlendirmeleri ile kendilerini serbest hissederek fazla rahat davranmaları disiplin problemlerine yol açacağı için etkinliğin amacı, planı gibi özellikler hakkında öğrenciler etkinlik öncesinde bilgilendirilebilir.

2. Planetaryumlara düzenlenen planlı bir gezinin yalnızca fen bilimleri dersi ve Dünya ve Evren konu alanı ile sınırlandırılmayıp diğer üniteler ve diğer derslerle de ilişkilendirilerek öğretim 
amaçlı kullanımı sağlanarak öğretmenler tarafından sene başında hazırlanan yıllık planlarda ders kazanımlarına uygun olarak yıl boyunca uygulanacak okul dışı eğitim aktivitelerine de yer verilebilir.

Bundan sonra yapılacak planların 5. sınıflardan başlanması önerilmektedir. Çünkü aynı konu alanı faklı kazanımları gerçekleştirmek üzere 5. sınıflarda 7 kazanım ile toplam kazanımların \%19,44'üne, 6 . sınıflarda 5 kazanım ile toplam kazanımların \%8,47'sine, 7 . sinıflarda ise 10 kazanım ile toplam kazanımların \%14,93'üne karşlık gelmektedir.

\section{KAYNAKÇA}

Arıc1, V.A. (2013). Fen eğitiminde sanal gerçeklik programlari üzerine bir çalişma: Güneş sistemi ve ötesi: uzay bilmecesi ünitesi örneği. Yüksek Lisans Tezi, Adnan Menderes Üniversitesi, Fen Bilimleri Enstitüsü İlköğretim Anabilim Dalı, Aydın.

Babaoğlu, G., \& Keleş, Ö. (2017). 6. Sınıf öğrencilerinin ‘Dünya', 'Ay' ve 'Güneş' kavramlarına yönelik algılarının belirlenmesi. Eğitimde Kuram ve Uygulama Dergisi, 13(4), 601-636.

Bahali, K. (2014, June). Astronomy education at al-khawarizmi astronomy centre. Proceedings of the 22nd International Planetarium Society Conference, Beijing, China.

Bodur, Z., \& Yıldırım, M. (2018). Sınıf dışı etkinliklerin ortaokul yedinci sınıf öğrencilerin akademik başarıları ve bilimsel süreç becerileri üzerine etkisi. Marmara Üniversitesi Atatürk Eğitim Fakültesi Eğitim Bilimleri Dergisi, 47(47), 125-140.

Bostan-Sarığlan, A., \& Kü̧̈üközer, H. (2017). Fen bilgisi öğretmen adaylarının okul dışı öğrenme ortamları ile ilgili görüşlerinin araştırılması. İnformal Ortamlarda Araştırmalar Dergisi, 2(1), $1-15$.

Bozdoğan, A. E. (2007). Bilim ve teknoloji merkezlerinin fen öğretimindeki yeri ve önemi. Yayımlanmamış Doktora Tezi, Gazi Üniversitesi Eğitim Bilimleri Enstitüsü, Ankara.

Bozdoğan, A. E. (2008). Fen bilgisi öğretmen adaylarının bilim merkezlerini fen öğretimi açısından değerlendirmesi: Feza Gürsey Bilim Merkezi örneği. Uludağ Üniversitesi Eğitim Fakültesi Dergisi, 21(1), 19-41.

Bozdoğan, A. E., \& Ustaoğlu, F. (2016). Planetaryumların öğretim potansiyeli hakkında fen bilimleri öğretmen adaylarının görüşleri. Türk Fen Eğitimi Dergisi, 13(1), 38-49.

Bozdoğan, A. E., \& Yalçın, N. (2006). Bilim merkezlerinin ilköğretim öğrencilerinin fene karşı ilgi düzeylerinin değişmesine ve akademik başarılarına etkisi: Enerji Parkı. Ege Eğitim Dergisi, $7(2), 95-114$.

Büyüköztürk, Ş. (2014). Deneysel desenler öntest-sontest kontrol grubu desen ve veri analizi (4. Bask1). Ankara: Pegem Akademi. 
Can, A. (2019). SPSS ile bilimsel araştırma sürecinde nicel veri analizi (7.Bask1). Ankara: Pegem Akademi.

Çankaya, B., \& Girgin, S. (2018). Artırılmış gerçeklik teknolojisinin fen bilimleri dersi akademik başarısına etkisi. Journal of Social and Humanities Sciences Research, 5(30), 4283-4290.

Çepni, S., \& Şenel Çoruhlu, T. (2014). Güneş sistemi ve ötesi: Uzay bilmecesi ünitesinde zenginleştirilmiş 5E öğretim modeline uygun hazırlanan öğrenme ortamlarının öğrenci başarısı üzerine etkisinin incelenmesi. Uludağ Üniversitesi Ĕ̆itim Fakültesi Dergisi, 27(2), 343-369.

Chastenay, P. (2016). From geocentrism to allocentrism: Teaching the phases of the moon in a digital full- dome planetarium. Research in Science Education, 46(1), 43-77.

Çiçek, Ö., \& Saraç, E. (2017). Fen Bilimleri öğretmenlerinin okul dışı öğrenme ortamlarındaki yaşantıları ile ilgili görüşleri. Ahi Evran Üniversitesi Kırşehir Eğitim Fakültesi Dergisi, 3(18), $504-522$.

Ertaş, H., \& Şen, A. İ. (2011). Planetaryumlar. C. Laçin Şimşek (Editör). Fen öğretiminde sınıf dışı öğrenme ortamları (s. 85- 103). Ankara: Pegem Akademi.

Eshach, H. (2007). Bridging In-school and out-of-school learning: Formal, non-formal, and informal education. Journal of Science Education and Technology, 16(2), DOI: 10.1007/s10956006-9027-1

Gülen, S. (2018). Determination of the effect of the planetarium activities on the students. European Journal of Education Studies, 5(2), 48-65.

Gürsoy, G. (2018). Fen öğretiminde okul dışı öğrenme ortamları. Turkish Studies Educational Sciences, 13(11), 623-649

Jarvis, T., \& Pell, A. (2005). Factors influencing elementary school children's attitudes toward science before, during, and after a visit to the UK National Space Centre. Journal of Research in Science Teaching, 42(1), 53-83. DOI: 10.1002/tea.20045

Jettner, F. C., \& Soroka, J. J. (1972). The planetarium in modern science education. Annals of the New York Academy of Sciences, 198, 178-191. DOI: 10.1111/j.1749-6632.1972.tb12720.x

Kulalıgil, A. (2016). Sinıf dışı öğrenme ortamlarında gerçekleşen öğretim uygulamalarının 5. sınıf fen bilimleri dersinde öğrencilerin akademik başarı, yaratıcılık ve motivasyonlarna etkisi. Yayınlanmamış Yüksek Lisans Tezi, Pamukkale Üniversitesi, Denizli.

Laçin Şimşek, C., \& Nuhoğlu, H. (2009). Fen konularına yönelik geçerli ve güvenilir bir ilgi ölçeği geliştirme. Sakarya Üniversitesi Ĕ̆itim Fakültesi Dergisi, 18, 28-41. 
Mallon, G. L., \& Bruce, M. H. (1982). Student achievement and attitudes in astronomy: An experimental comparison of two planetarium programs. Journal of Research in Science Teaching, 19(1), 53-61. DOI: 10.1002/tea.3660190108.

Önder, A., Abacı, O., \& Kamaraj, I. (2009). Müzelerin eğitim amaçlı kullanımı projesi: İstanbul arkeoloji müzesindeki Marmara örneklemi. Pamukkale Üniversitesi Eğitim Fakültesi Dergisi, 2009(1), 102-117.

Özcan, H., \& Yılmaz, Ş. (2018). Planetaryum gezisi ile fen bilgisi öğretmen adaylarının astronomi kavramlarındaki değişimin incelenmesi. Necatibey Eğitim Fakültesi Elektronik Fen ve Matematik Eğitimi Dergisi (EFMED), 12(1), 392-418.

Palmer, J. C. (2007). The Efficacy of planetarium experiences to teach specific science concepts. Dissertation Abstracts International, B: The Sciences and Engineering, 68, 939.

Petrie, K. B. (2013). Early childhood learning in preschool planetarium programs. Unpublished Master Thesis, University of Washington. ABD.

Plummer, J. D. (2009). Early elementary students' development of astronomy concepts in the planetarium. Journal of Research in Science Teaching, 46(2), 192-209.

Plummer, J. D., Kocareli, A., \& Slagle, C. (2014). Learning to explain astronomy across moving frames of reference: Exploring the role of classroom and planetarium-based instructional contexts. International Journal of Science Education, 36(7), 1083-1106. DOI: 10.1080/09500693.2013.843211

Ramey Gassert, L. (1997). Learning science beyond the classroom. The Elementary School Journal, 97(4), 433-450.

Ridky, R. W. (1974). A study of planetarium effectiveness on student achievement, perceptions and retention. Paper presented at the The Annual Meeting of the National Association for Research in Science Teaching, 47th, Chicago, Illinois. http: // www.eric.ed.gov/ERICWebPortal/contentdelivery/servlet/ERICServlet?Accno= = ED091207 adresinden alınmıştır.

Selanik-Ay, T., \& Erbasan, Ö. (2016). Sınıf öğretmenlerinin okul dışı öğrenme ortamlarından yararlanmaya ilişkin görüşleri. Journal of Education and Future, 10, 35-50.

Sontay, G., Tutar, M., \& Karamustafaoğlu, O. (2016). Okul dışı öğrenme ortamları ile fen öğretimi hakkında öğrenci görüşleri: Planetaryum gezisi. İnformal Ortamlarda Araştırmalar Dergisi, $1(1), 1-24$.

Türk, C. (2010). İlköğretim temel astronomi kavramlarının öğretimi. Yayımlanmamış Yüksek Lisans Tezi, Ondokuz Mayıs Üniversitesi, Samsun. 
Türkmen, H. (2015). İlkokul öğretmenlerinin sınıf dışı ortamlardaki fen öğretimine bakış açıları. Journal of European Education, 5(2), 47-55.

Yener, D., Aksüt, P., Kiras, B., \& Yener, Y. (2018). Fen bilgisi öğretmen adaylarının bilim gezisi ve fen- teknoloji- toplum- çevre konusundaki görüşleri: Müzede bilim örneği. Başkent University Journal of Education, 5(2), 212-224.

Yılmaz, E., \& Laçin Şimşek, C. (2017). Güneş sistemi ve ötesi: Uzay bilmecesi öğretmenler bu üniteyi nasıl işliyor? Sakarya University Journal of Education, 7(2), 252-267.

Yılmaz, H., \& Huyugüzel Çavaş, P. (2007). Fen öğrenimine yönelik motivasyon ölçeğinin geçerlik ve güvenirlik çalışması. İlköğretim Online, 6(3), 430-440.

Yu, K.C., Sahami, K., Sahami, V.A., \& Sessions, L.C. (2015). Using a digital planetarium for teaching seasons to undergraduates. Journal of Astronomy \& Earth Sciences Education, 2(1), 33-50. 